\title{
The Use of Application Namely Quizizz in Elementary School Students' Outcomes
}

\author{
Nurrohmatul Amaliyah ${ }^{1, *}$, Luluk Regita Handayani² \\ 1,2) Universitas Muhammadiyah Prof. Dr. HAMKA, Jl. Tanah Merdeka No.20, RT.11/RW.2, Rambutan, Kec. \\ Ciracas, Kota Jakarta Timur, Daerah Khusus Ibukota Jakarta. Telp.: (021)7394451, Fax: 7261226, \\ Email: info@uhamka.ac.id \\ *Corresponding author: nurramaliyah@uhamka.ac.id
}

\begin{abstract}
Although Indonesia is the fourth most populous country in the world, the quality of its human resources is still low. One of the causing problems is the teacher's hesitation in choosing learning models, and the minimum use of technology in schools. This study aims to determine the influence of science learning outcomes by using the learning model TGT assistant application "Quizizz" on the fourth-grade students of SDN Cakung Barat 07 Jakarta Timur. The research method used is a quantitative research method with a type of Quasi-Experimental design, with purposive random sampling using IV-A as experimental class and IV-B as a control class. Students' outcomes were measured by 20 multiple-choice questions, which had previously been tested for validity and reliability. The requirement test in this study includes the normality test using the ChiSquare test formula, and the normality test using Fisher's test formula. While the hypothesis test is using the t-test formula. So that the results are $\mathrm{H}_{0}$ is accepted, which states that there is no significant influence on learning by using the learning model TGTassistant application "Quizizz" on the fourth-grade students of SDN Cakung Barat 07 Jakarta Timur.
\end{abstract}

Keywords: TGT Learning Model, Quizizz, Science learning outcomes.

\section{INTRODUCTION}

Indonesia is the fourth most populous country in the world. However, Indonesia still has relatively low human resources quality. Therefore, education in Indonesia continues to be developed in order to prepare a higher quality nation for their next generation in the future. Indonesia continues to make changes to its curriculum that keeps up with the times. However, practically, many factors influence the success of education. There are many obstacles facing education in Indonesia. Such as the teacher's minimum comprehensive by using the various learning models and the lack of technologies' involvement in the schools' learning process.
The pandemic caused by the Coronavirus, which was first discovered in Wuhan in 2019 (Covid-19) that has spread throughout the world, has also significantly impacted various human sectors' life. No exception in Indonesia. The Indonesian government strictly enforces some policies, namely Work from Home and DistanceLearning, to reduce community infections. As a result of Indonesia's education affected by the policies, all stakeholders, such as the government, teachers, and the students, need to make some changes and adjustments to be implemented so that learning objectives can be adequately achieved.

A significant change from this distance-learning policy is that the learning process in schools, which was previously done by face-to-face interaction has turned into online learning, which emerges many new challenges for 
all parties involved. One crucial aspect of the learning process that cannot be implemented optimally is the learning model. This condition also places technology as an essential aspect of learning activities from home.

One of the essential components that can determine the learning outcomes is the learning model. The learning model wraps the whole learning objectives to class management techniques [1]. One of the active learning models that can be applied in schools is the cooperative learning model. The cooperative learning model is a learning model that collects some of the students into small groups. This learning model deals with studentcentred learning. This learning model replaces the teachers' role as a facilitator [2]. The cooperation in this learning model can occur due to a learning system consisted of many students. Students can learn from their own experience or the expertise and knowledge of other students [3].

The Cooperative Learning model emphasizes group collaboration. Each member of the group's involvement and cooperation affects the final group results' success. Therefore, the assignment given must be cooperative, which triggers interaction between students. Both take place physically, verbally, and emotionally [4]. There are many variances of the cooperative learning model, such as the Teams Games Tournament (TGT) learning model. Nur and Wikan, stated that the TGT learning model could be applied to all levels of education [5]. The TGT learning model is a learning model that requires the involvement of many students. This learning model contains games and tournaments that can increase student activity so that there is a dimension of joy in it [6]. In the TGT learning model, students act as a representative for their group to compete with other groups' representative, whose primary purpose is to collect scores or points for their respective groups [7]. In this learning model, students in groups can interact and communicate with other students in the same group to achieve the learning goals.

The use of technology is intended to facilitate human life. For example, technology can be used in education. The use of Quizizz application is one example of the technology utilizations. The Quizizz application is a unique game-based educational application, which offers several features, just like a game. There are avatars, music, and exciting animations that can bring a new atmosphere to the student learning evaluation process [8]. The Quizizz application can be accessed through the device, with multiple players at the same time. This feature simplifies the distance-learning evaluation, which indirectly helps an online learning process. Virtually, the Quizizz application is similar to Kahoot. However, Quizizz can provide more convenience and advantages. The Quizizz application does not require a large layer so that it can be accessed via a smartphone. Questions in the Quizizz application can also be given to students as homework [9]. This is in line with the advantages that this application finds most useful.
This means that the process can be done anywhere, anytime, even outside student class hours. Ever since Quizizz could provide these beneficial advantages, learning can be carried out flexibly [10].

Natural Sciences, which also known as Ilmu Pengetahuan Alam (IPA) in Bahasa, is an English translation [11]. Natural Science (IPA) is a concept, understanding, process, and application with a broad discussion scope. However, science is only limited to things, events, or phenomena that are rational and objective. Natural sciences are obtained through systematic observations and experiments and based on concepts previously agreed upon by the scientific community. Science is also a branch of science that can create technology to facilitate human needs.

The acquisition of learning outcomes is used as a benchmark of students' understanding after they are studied. Learning outcomes are the level of student success in learning and understanding the subject matter in school to be measured and expressed in values [12]. Learning outcomes are processes of an individual trying to obtain a form of change or ability that contains value and attitudes that show a change for the better, which is stated by the results of the test score.

However, the current pandemic around the world is also affecting education in Indonesia. The Indonesian Ministry of Education and Culture decided to implement an online school, which generated new challenges for schools that had previously never implemented online school services. This policy aims to prevent the high number of students who are at risk of being exposed to Covid-19 [13]. The implementation of this online school policy makes the previously planned learning model hardly implemented.

The number of schools that have never had a distancelearning experience has caused limitations in selecting the proper learning media. These options are limited to applications such as WhatsApp, Zoom, or Google Meet. Nevertheless, as the many applications offered, WhatsApp is elected to be the most prominent choice and have the most voters as an application that is free, easy, and the most commonly owned by the students' parents.

Using Google Meet and Zoom is considered expensive because it consumes a lot of internet quota. Besides, the application Zoom Meetings requires complicated procedural rules, which are considered very burdensome for both students and parents [14]. Therefore, the Quizizz application can be used as an alternative media to help the learning and teaching process during the Covid-19 pandemic.

This study aims to see the influence of the Teams Games Tournament (TGT) learning model, assisted by the Quizizz application, on the fourth-grade students' science learning outcomes at SDN Cakung Barat 07 East Jakarta, during this distance-learning process. 


\section{METHOD}

Participant: This research was conducted at SDN Cakung Barat 07, East Jakarta City. Involves 60 students from two classes that have been designated as research sites in the second semester of the 2019/2020 school year.

Method: The method used in this research is the method of Quasi-Experimental Design. The quasi- experimental design is a research design with a control group, which cannot fully control external variables that affect the experiment [15]. One type of research design in quasi-experimental design is the nonequivalent group posttest-only design. This research only gives one sample class treatment, while the other class role as the control class and data collection are obtained through the final treatment results (TABLE 1).

TABLE 1. Research Design

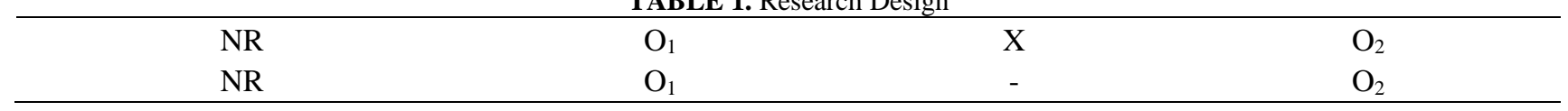

Sampling method: In this study, two classes were used as samples. Namely, class IV-A as the experimental class, and class IV-B as the control class. Both the experimental class and the control class have 30 students in each class. The sampling technique used in this research is the purposive sampling technique. That is, sampling is carried out based on specific considerations [16]. They considered that these two sample groups have the same lesson schedule and study the same subject. Also, it is assumed that these two sample groups have an equivalent ability so that the amount of the sample in this study was 60 students, which were divided into two classes (TABLE 2).

TABLE 2. Samples

\begin{tabular}{lcc}
\hline & Class & Students \\
\hline IV-A Class & 30 \\
IV-B Class & 30 \\
\hline Amount & $\mathbf{6 0}$ \\
\hline
\end{tabular}

Instrument and Procedure: The type of instrument used in collecting the primary data in this study was the test method. The test method is used to obtain data on student science learning outcomes. The test used is a multiple-choice objective test. This test was given to the two-sample classes after treatment with the learning model Teams Games Tournament (TGT) and conventional learning. Before being used and given to the two-sample classes, this instrument was first tested to determine its validity (validity) and how reliable the instrument was (reliability).

Testing the instrument's validity was carried out to see the validity of a research instrument using the biserial correlation point formula. Meanwhile, to measure the level of reliability, or to what extent a research instrument is reliable, a reliability test is performed using the $\mathrm{KR}$ formula. 20. After the two tests above, it is gained with the total amount of 20 questions were valid and reliable. The method used in this research is a documentation method. This study's supporting documents were a list of the fourth-grade students of SDN Cakung Barat 07 who were sampled, and the second-semester scores of the fourthgrade students in 2019/2020.

The Teams Games Tournament (TGT) learning model was carried out in the experimental class. In its application, the teacher first presents the learning material, which will later become material for students' discussion. Students are then divided into small heterogeneous groups, where each group consists of four to six students. Further, students are asked to discuss the material delivered by the teacher with their group members.

After discussing, students play a game or game. This game can determine students' level of ability so that when conducting tournaments, students will be grouped to compete with students from other groups of equal ability. After the game is over, students are asked to represent their group to compete with other representatives at the tournament table to collect points for their respective groups. In the final step, the teacher performs team recognition. The following is an illustration of the tournament table placement in the TGT learning model (FIGURE 1). 


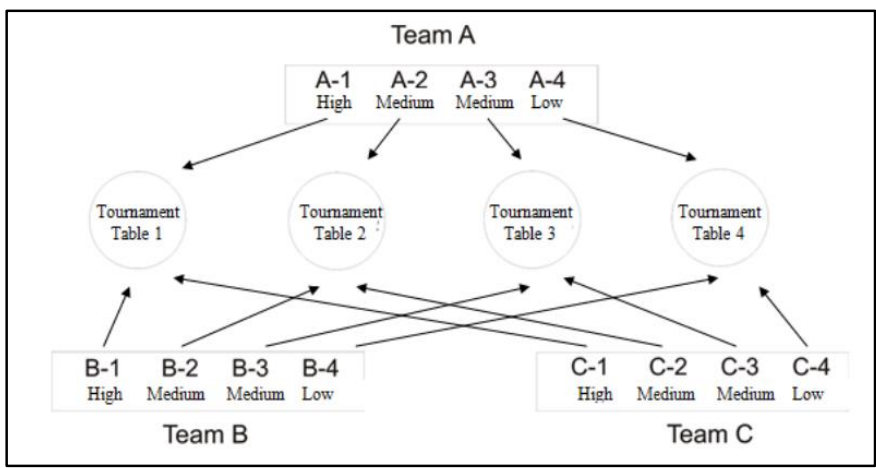

FIGURE 1. The Tournament Table

In the data analysis technique, the prerequisite analysis test was conducted first. Which is the normality test to determine whether or not the sample class's data distribution is normal. Furthermore, the homogeneity test was carried out to find out whether the two classes used as samples had the same variance or not. After the two prerequisite tests for analysis test were carried out, and it was stated that the data from the two classes sampled in this study were normally distributed and homogeneous, then hypothesis testing could be continued using the Tukey test or t-test.

\section{RESULTS AND DISCUSSION}

Based on the research that has been done, the data were obtained from the two research sample classes post-test results-namely, the experimental class and the control class. The experimental group and the control classes' data post-test were calculated, and their values were determined. So that they can be determined mean, median, and modus to facilitate the calculation of further data processing. The research data obtained are as follows:

\subsection{Post-test results for the experimental and control classes}

Both the two sample classes were given different treatments; the data calculation results were obtained posttest from the experimental group and the control class. The data is presented in table form to facilitate reading the learning outcome data from the two sample classes. The following is a comparison of the science learning outcomes obtained from the two sample classes of this study (TABLE 3):

TABLE 3. Post-test Results of Science Learning Outcomes

\begin{tabular}{lcc}
\hline \multicolumn{1}{c}{ Aspect } & Experimental class & Control class \\
\hline Highest score & 100 & 100 \\
Lowest score & 60 & 60 \\
Mean & 85,633 & 83,067 \\
Median & 86,227 & 84,000 \\
Mode & 85,750 & 84,700 \\
Standard deviation & 8,416 & 9,169 \\
\hline
\end{tabular}

\subsection{Comparison of Post-test Results for Experiment Class and Control Class}

class and control class data, this data can be seen in the histogram graph as shown below (FIGURE 2):

In addition to using tables, to make it easier to read and conclude the differences in the results of the experimental 


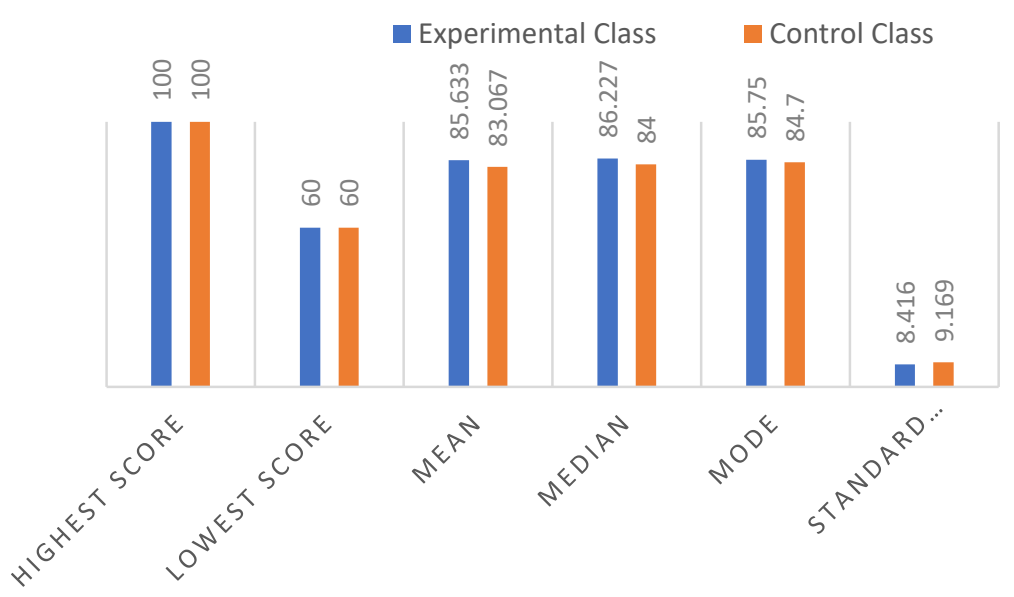

FIGURE 2. Graph of Data Differences in Science Learning Outcomes for Experiment Class and Control Class

The graph above shows that there is only a slight difference in science learning outcomes between the experimental class and the control class. The data from the students' science learning outcomes is then calculated, and the value is determined to facilitate the calculation of further data processing.

\subsection{Normality test results for the experimental and control classes}

To analyse the students' science learning outcomes, the researcher first used the analysis requirements test. It is using the normality test. The normality test used in this study using the Chi-Square test formula. It can be stated that the data normally distributed if the ChiSquared $_{\text {count }}<$ Chi - Squared $_{\text {table }}($ TABLE 4).

TABLE 4. Normality Test Results

\begin{tabular}{lcccc}
\hline \multicolumn{1}{c}{ Category } & $\boldsymbol{X}_{\text {count }}^{\mathbf{2}}$ & $\boldsymbol{X}_{\text {table }}^{\mathbf{2}}$ & Criteria & Annotation \\
\hline Experimental & 5,502 & 7,815 & \multirow{2}{*}{$X_{\text {count }}^{2}<X_{\text {table }}^{2}$} & \multirow{2}{*}{ NORMAL } \\
Control & 3,947 & 7,815 & \\
\hline
\end{tabular}

From the calculation results obtained in the table above, it can be concluded that the data from the two samples used in this study are normally distributed. Thus, the next analysis prerequisite test calculation, namely the homogeneity test, can be carried out.

\subsection{Homogeneity test results for the experimental and control classes}

In addition to conducting the normality test, the researcher also carried out a homogeneity test to analyse the students' science learning outcomes. The homogeneity test used in this study using the Fisher's test formula (TABLE 5).

TABLE 5. Homogeneity Test Results

\begin{tabular}{lccccc}
\hline \multicolumn{1}{c}{ Category } & Variances & $\boldsymbol{F}_{\text {count }}$ & $\boldsymbol{F}_{\text {table }}$ & Criteria & Annotation \\
\hline Experimental & 70,832 & \multirow{2}{*}{1,186} & \multirow{2}{*}{1,861} & \multirow{2}{*}{$F_{\text {count }} \leq F_{\text {table }}$} & \multirow{2}{*}{ HOMOGENY } \\
Control & 84,062 & & & \\
\hline
\end{tabular}

\subsection{Hypothesis test results for the experimental and control classes}

From the results of the analysis requirements test, which includes the normality test and the homogeneity test, it is known that the two sample classes are normally distributed and have homogeneous variances. So, the calculation can be continued by testing the research hypothesis using the Tukey-test or T-test (TABLE 6). 
TABLE 6. Hypothesis Test Results

\begin{tabular}{lllccc}
\hline \multicolumn{1}{c}{ Category } & $\mathbf{N}$ & Mean & $\boldsymbol{t}_{\text {count }}$ & $\boldsymbol{t}_{\mathbf{0 , 0 5}(\mathbf{5 8})}$ & Conclusion \\
\hline Experimental & 30 & 85,663 & \multirow{2}{*}{1,139} & \multirow{2}{*}{2,002} & Does Not \\
Control & 30 & 83,067 & & & Significant \\
\hline
\end{tabular}

Based on the results of calculations that have been done above, it is obtained $t_{\text {count }}=1.139$. While the $t_{\text {table }}$ $=2.002$, at the significance level of $\alpha=0.05$, with 58 degrees of freedom. Based on the value of both the $t_{\text {count }}$ and $t_{\text {table }}$ above, it is known that the $t_{\text {count }} \geq t_{\text {table }}$. This result indicates no significant difference in the average scores of the students' science learning outcomes between the experimental class using the TGT model and the control class using the conventional learning model. Or in other words, the difference in students' learning outcomes between the two classes in this study is just a coincidence.

\section{CONCLUSIONS}

From the results of the calculation with acceptance, it can be stated that there is no influence of the Teams Games Tournament assisted by the "Quizizz" application on the science learning outcomes of fourth-grade students of SDN Cakung Barat 07 East Jakarta. The results of this study contradict the results of previous studies with the same theme. The research conducted by Sakdiah \& Sasmita (2018) concluded an increase in student learning outcomes in class XI SMA Negeri 4 Sungai Penuh, Jambi by using the TGT learning model [17].

Furthermore, the same results were also concluded in the research of Maulidina (2018), which concluded that there was a positive influence on the learning outcomes of fifth-grade students at SDN Tegalgede 01 Jember, using the TGT type cooperative learning model [18]. Wibawa (2019), in his research, also stated positive results from using the Quizizz application on student learning outcomes [19].

However, the results of previous studies with the theme of the TGT learning model indicated a positive influence on student learning outcomes. Therefore, the cooperative learning model with the type of the Teams Games Tournament (TGT) should still be a consideration in choosing a learning model. This is intended to provide a choice of variations in learning models to achieve an optimal learning purpose.

\section{REFERENCES}

[1] R. Maskun; Valensy, Teori Belajar dan Pembelajaran. Yogyakarta: Graha Ilmu, 2018.

[2] O. N. Pratiwi, I. G. B. B. Nugraha, S. H. Supangkat, and B. Rahardjo, "Web application for Jigsaw-based cooperative learning," Proc. - Int. Conf. ICT Smart Soc. 2013 "Think Ecosyst. Act
Converg. ICISS 2013, pp. 354-357, 2013.

[3] D. A. Vidhate and P. Kulkarni, "Performance enhancement of cooperative learning algorithms by improved decision making for context based application," Int. Conf. Autom. Control Dyn. Optim. Tech. ICACDOT 2016, pp. 246-252, 2017.

[4] A. Suprijono, Cooperative Learning. Yogyakarta: Pustaka Pelajar, 2015.

[5] Trianto, Model Pembelajaran Terpadu. Jakarta: Bumi Aksara, 2015.

[6] S. R. Sa'adah, "Implementation of Cooperative Learning Model with Teams Games Tournament (TGT) Method to Improve Interests and Learning Outcomes," Classr. Action Res. J., vol. 1, no. 2, pp. 65-72, 2017, doi: 10.17977/um013v1i42017p156.

[7] Rusman, Model-Model Pembelajaran Mengembangkan Profesionalisme Guru. Depok: Raja Grafindo, 2014.

[8] F. Zhao, "Using Quizizz to Integrate Fun Multiplayer Activity in the Accounting Classroom," Int. J. High. Educ., vol. 8, no. 1, pp. 37-43, Jan. 2019.

[9] H. Akhtar, N. Hasanati, and Istiqomah, "GameBased Learning: Teachers' Attitude and Intention To Use Quizizz in the Learning Process," 2nd Int. Conf. Educ. Assess. Policy, no. Iceap, pp. 49-54, 2019.

[10] L. S. L. Purba, "Peningkatan Konsentrasi Belajar Mahasiswa Melalui Pemanfaatan Evaluasi Quizizz Pada Mata Kuliah Kimia Fisika I," J. Din. Pendidik., vol. 12, no. 1, pp. 29-39, 2019.

[11] B. Muakhirin, "Peningkatan Hasil Belajar IPA Melalui Pendekatan Pembelajaran Inkuiri Pada Siswa Sd," J. Ilm. Guru Caraka Olah Pikir Edukatif, vol. 1, no. 1, pp. 51-57, 2014.

[12] A. Susanto, Teori Belajar di Sekolah Dasar. Jakarta: Prenada Media Group, 2013.

[13] A. Abidah, H. N. Hidaayatullaah, R. M. Simamora, D. Fehabutar, and L. Mutakinati, "The Impact of Covid-19 to Indonesian Education and Its Relation to the Philosophy of 'Merdeka Belajar,"' Stud. Philos. Sci. Educ., vol. 1, no. 1, pp. 38-49, 2020, doi: 10.46627/sipose.v1i1.9.

[14] V. Dewangga, P. Ihsan, and A. Dina, "Challenges of conducting distance learning during Covid-19 pandemic: the case of Google classroom and WhatsApp," PROCEDING “ Int. WEBINAR Educ. 2020", pp. 11-17, 2020. 
[15] Sugiyono, Metode Penelitian Kuantitatif, Kualitatif, dan $R \& D$. Bandung: Alfabeta, 2014.

[16] L. A. Palinkas, S. M. Horwitz, C. A. Green, J. P. Wisdom, N. Duan, and K. Hoagwood, "Purposeful Sampling for Qualitative Data Collection and Analysis in Mixed Method Implementation Research," Adm. Policy Ment. Heal. Ment. Heal. Serv. Res., vol. 42, no. 5, pp. 533-544, 2015, doi: 10.1007/s10488-013-0528-y.

[17] H. Sakdiah and P. R. Sasmita, "Pengaruh Model Pembelajaran TGT Berbantukan Media PhET
Dalam Meningkatkan Hasil Belajar," J. Pendidik. Fis., vol. 6, no. 2, pp. 65-70, 2018.

[18] Z. Maulidina, "Pengaruh Model Pembelajaran Kooperatif Tipe Teams Games Tournament (TGT) Berbantuan Media Teka Teki Silang Terhadap Hasil Belajar Siswa di SDN Tegalgede 01 Jember," Universitas Jember, 2018.

[19] R. P. Wibawa, R. I. Astuti, and B. A. Pangestu, 'Smartphone-Based Application 'quizizz' as a Learning Media,” Din. Pendidik., vol. 14, no. 2, pp. 244-253, 2019 